\title{
Variations in Hematological, Biochemical and Immunological Parameters in Labeo rohita Fed with Different Levels of Aerva javanica Supplementation Diet
}

\author{
S. Ananda Kumaran*, P. S. ArunaDevi \\ Department of Zoology, Sri Vasavi College, India
}

Received December 5, 2019; Revised February 26, 2020; Accepted March 12, 2020

Copyright $\subseteq 2020$ by authors, all rights reserved. Authors agree that this article remains permanently open access under the terms of the Creative Commons Attribution License 4.0 International License

\begin{abstract}
In the present study, Aerva javanica (in Powder form) was used to evaluate its effects on Hematological, Biochemical and Immunological Parameters of Labeo rohita fingerlings (fresh water fish). A total of 50 Labeo rohita were randomly distributed in five treatments including a control group and four experimental groups. Aerva javanica powder at the rate of $0.5 \mathrm{~g}, 1.0 \mathrm{~g}, 1.5 \mathrm{~g}$, and $2.0 \mathrm{~g}$ were added to the feed. The fish were fed for 60 days in fiber water tanks. After 60 days, end of cultured the Hematological, Biochemical and Immunological studies were done in fish samples (control, Exp-1, 2, 3 and 4 groups). The results showed significant $(p<0.05)$ differences in the amount of hemoglobin, Rbc, Wbc, neutrophil, lymphocyte, eosinophil, hct, mcv, mch, mchc, total protein, albumin, globulin, blood glucose, lysozyme, phagocyte, Nbt, Sod, and catalase, in the treatments compared to the control group at the end of the cultured. The results showed that Aerva javanica powder has the effect of an immune system booster and using the powder form in Particular at the level of $1.5 \mathrm{~g}, 2.0 \mathrm{~g}$ as an immune stimulant in the diet of Labeo rohita can be effective in preventing disease in this species.
\end{abstract}

Keywords Aerva javanica, Labeo rohita, Hematological, Biochemical, Immunological

\section{Introduction}

Aquaculture is playing a major role globally in tackling issues of food and nutritional security, livelihood and economy. Annual growth rate of aquaculture is more than $80 \%$ and producing about $4.4 \%$ of world fish production (FAO 2002). According to a recent report published by the $F A O$, world aquaculture has grown significantly in the past 50 years. It is mainly contributing to the increase in export earning, income, employment generation and food nutritional security for the developing countries. Emerging diseases constitutes an increasingly serious threat and health problem in aquaculture by limiting the survival, growth and production of farmed fish. In view of increased cost of production and reduced marginal profit in carp culture enterprising farmers is using fresh water fish, Labeo rohita as alternative species for culture. In commercial aquaculture, antibiotics were primarily used for deterrence and control of the diseases and hormones were utilized for improved growth, however, the main disadvantage of antibiotics and hormones are that they are not cost-effective. Several researchers across the world are trying to find novel, cost-effective and proficient compounds of plant origin for the disease prevention and to promote growth in aquaculture [1]. Eventually, all medicinally active herbs contain potential ingredients which possess several physiological activities [1]. Numerous medicinal palnts are being used in aquaculture which comprises of plants such as Cynodon dactylon, Azadirachta indica, Allium sativum, Tridax procumban and Phyllanthus emblica [2]. The aim of this paper is to review current research work being carried out this study was performed to evaluate the effects of four doses of Aerva javanica on hematological, biochemical, immunological parameters of this valuable species Labeo rohita. 
Table 1. Feed Formulation used for the study

\begin{tabular}{|c|c|c|c|c|c|}
\hline FEED & $\begin{array}{l}\text { weight of feed } \\
\text { (control) (ingrm) }\end{array}$ & $\begin{array}{l}\text { weight of feed } \\
\text { (Exp-1)(in grm) }\end{array}$ & $\begin{array}{l}\text { weight of feed } \\
\text { (Exp-2) (in grm) }\end{array}$ & $\begin{array}{l}\text { weight of feed } \\
\text { (Exp-3) (in grm) }\end{array}$ & $\begin{array}{l}\text { weight of feed } \\
\text { (Exp-4) (in grm) }\end{array}$ \\
\hline Fish meal & 137.5 & 137.5 & 137.5 & 137.5 & 137.5 \\
\hline Groundnutcake meal & 192.5 & 192.5 & 192.5 & 192.5 & 192.5 \\
\hline soya bean meal & 50 & 50 & 50 & 50 & 50 \\
\hline Tapioca flour meal & 50 & 50 & 50 & 50 & 50 \\
\hline Rice bran meal & 50 & 50 & 50 & 50 & 50 \\
\hline Cod liver oil & 5 & 5 & 5 & 5 & 5 \\
\hline Egg albumin (white) & 5 & 5 & 5 & 5 & 5 \\
\hline $\begin{array}{l}\text { Supradyn (vitamin and } \\
\text { mineral mixed) }\end{array}$ & 10 & 10 & 10 & 10 & 10 \\
\hline $\begin{array}{c}\text { Aerva javanica (powder } \\
\text { form) }\end{array}$ & - & 0.5 & 1.0 & 1.5 & 2.0 \\
\hline Total weight of feed & $500 \mathrm{~g}$ & 500.5 & 501 & 501.5 & 502 \\
\hline
\end{tabular}

\section{Materials and Methods}

\subsection{Experimental Design}

The study was carried out in the Post-Graduate and Research department of zoology, Sri Vasavi College, Erode, Tamilnadu. The experiment was conducted in laboratory condition for sixty days. Indian major carps Labeo rohita were obtained from government nursery fish farm in Bhavanisagar dam, Sathyamangalam, Erode district at Tamilnadu. The collected fish was transferred alive in polyethylene bags and brought to the laboratory and acclimated for three days feeding on mixed diet. Fifty acclimated Labeo rohita of similar size were randomly distributed in fiber tank filled with unchlorinated water. Constant aeration was provided to each container using air compressor.

\subsection{Experimental Diets}

The formulation of experimental diet was prepared using ingredients given in table 1 .

\subsection{Collection of Blood Samples}

At the end of 60 days of fish cultures of Labeo rohita were fed with Aerva javanica in powder form to evaluate the hematological, bio chemical and immunological parameters and to compare with control and experimental groups. Blood samples from the caudal vein of 10 fishes from each of five groups were taken by using $2 \mathrm{ml}$ tuberculin syringes with 24 gauge needles and the blood was collected in serological tubes. The blood (without anticoagulant) collected from fish was kept overnight at $4^{0}$ $\mathrm{C}$ for serum separation. The serum was separated by spinning down at $3000 \mathrm{rpm}$ for $15-20 \mathrm{~min}$ in centrifuge. The supernatant was collected in sterile vials and stored a $-20^{\circ} \mathrm{C}$ for further hematological, biochemical, and immunological analysis.

\subsection{Hematological Examination}

Blood samples were analyzed following routine methods adopted in hematology [3,4] The total red blood cell counts $\left(\mathrm{RBC} \times 10^{6} / \mathrm{ml}\right)$ were determined in a 1:200 dilution of the blood sample in Hayem's solution and total white blood cell counts (WBC $\times 10^{3} / \mathrm{ml}$ ) in a $1: 20$ dilution of the blood sample with a Neubauer hemocytometer. The hematocrit and leucocrit Percentages were determined in duplicate using micro hematocrit heparinized capillary tubes of $75 \mu \mathrm{l}$ volume and a micro hematocrit centrifuge at $15000 \mathrm{rpm}$ for $5 \mathrm{~min}$ [5] The percentages of erythrocyte and leucocyte volumes were calculated by overlaying the tubes on a sliding scale hematocrit reader. The hemoglobin $\left(\mathrm{Hb}, \mathrm{gdL}^{-1}\right)$ concentrations determined by the cyanomethaemoglobin method [6] using a haemoglobin reagent set (pars Azmun Diagnostics). All the values of red blood cell indices, the mean values of cell hemoglobin ( $\mathrm{MCH} \mathrm{pg})$, cell hemoglobin concentration (MCHC\%) and cell hemoglobin volume (MCV fl) were calculated according to wintrobe formulae [7]. The differential leukocytes count was carried out using blood smears stained with wright-giemsa. The percentage composition of leukocytes was determined based on their identification characters listed [8].

\subsection{Biochemical Examination}

For Biochemical analysis, the blood collected was centrifuged at $4000 \mathrm{rpm}$ for $10 \mathrm{~min}$ and blood serum was separated, then the serum extracted was analyzed on the spectrophotometer (T80+ UV/VIS) using an analyzer (Bioanalytic Diagnostic industry,co.) [6,9].The Biochemical parameters that were detected during the test included glucose, total protein, albumin and globulin.

\subsection{Immunological Examination}


Phagocytic activity was estimated by using the method modified by Siwicki and Anderson [10]. Approximately 100 cells were counted in random fields of view, recording the number of phagocytic cells, and phagocytic activity (PA) was determined. PA $=$ (number of phagocytic cells with engulfed bacteria/ number of total cells) x 100 . The respiratory burst of the neutrophils and monocytes was quantified by the reduction of nitroblue tetrazolium (NBT) to formazan as a measure of the production of oxygen radicals (Siwicki and Anderson 1993) [11]. Serum lysozyme was assessed using the turbidometric assay (Ellis 1990) [3] Superoxide dismutase (SOD) activity was determined according to the method of MC cord and Firdovich (1969) [12]. Catalase (CAT) activity was determined according to the method of Aebi (1974) [13].

\subsection{Statistical Analysis}

Statistical analysis was performed by using spss (version 23). Data are presented as mean \pm SD. Data were analyzed by one way of variance analysis ANOVA. The significant means were compared by Duncan test and a $\mathrm{p}<0.05$ was considered statistically significant.

\section{Results}

The hematological, biochemical, immunological parameters of Labeo rohita fed with different level of feed formulation was shown in Tables 2, 3 and 4 . In this parameters the results show significant difference $(\mathrm{P}<0.05)$. The blood samples were collected after 60 days at the end of experimental period. The hemoglobin count was significantly higher at exp-3 and $4(33.8 \pm 0.01)$ when compared to exp-2 $(32.8 \pm 0.02)$. The maximum WBC were recorded at exp-4 (28.6 \pm 2$)$ and minimum in exp-3 $(27.7 \pm 2.64)$. The minimum neutrophil value was observed in exp-1 (29.2 \pm 0.1$)$ and maximum value was recorded in exp-4 (30.3 \pm 0.05$)$. Lymphocytes maximum value was recorded in exp-4 (68.2 \pm 0.15$)$ and minimum in exp-1 (63.1 \pm 0.05$)$. Monocyte maximum value was recorded in exp-4 (6.2 \pm 0.1$)$ and minimum in exp-1 $(5.1 \pm 0.1)$. The RBC count was significantly higher at exp-4 (2.98 \pm 0.01$)$ when compared to exp-1 $(2.18 \pm 0.01)$. The Hematocrit were recorded and the maximum value was observed in exp-2 and exp-4 (16.8 \pm 0.01$)$ compared to exp-1 (16.4 \pm 0.03). The red cell indices like MCV, MCH and MCHC values were calculated, minimum MCV value was observed in exp-1 (71.6 \pm 0.01$)$ and maximum value was recorded in exp-3 (78.82 \pm 0.02$)$ and maximum values for MCH were recorded in exp-4 (68.8 \pm 0.01$)$ and minimum in exp-1 $(66.8 \pm 0.05)$. MCHC maximum value was recorded in exp-4 $(98.1 \pm 0.05)$ and minimum in exp-1 $(93.1 \pm 0.11)$. The biochemical parameters like total protein, albumin, globulin, blood glucose values were calculated, maximum total protein value was observed in exp-4 (8.61 \pm 0.01$)$ and minimum value was recorded in exp-1 (7.12 \pm 0.02$)$ and Albumin maximum values was recorded in exp-4 (4.92 \pm 0.02$)$ and minimum in exp-1 (4.12 \pm 0.02$)$. Globulin minimum value was recorded in exp-1 (3.31 \pm 0.01$)$ and maximum in exp-4 (4.21 \pm 0.05$)$ and Blood glucose maximum value was recorded in exp-4 $(143.3 \pm 1.5)$ and minimum in exp-1 (132.3 \pm 1.5$)$. The immunological parameters like lysozyme, phagocytes, NBT, SOD, catalase values were calculated, maximum lysozyme value was observed in exp-4 (53.2 \pm 0.15$)$ and minimum value was recorded in exp-2 (46.2 \pm 0.15$)$. Phagocytes minimum value was recorded in exp-2 (111 \pm 1$)$ and maximum in exp-4 (162 \pm 1$)$. NBT maximum value was recorded in exp-4 (15.3 \pm 0.5$)$ and minimum in exp-1 (11.6 \pm 1.15$)$. SOD minimum value was recorded in exp-1 $(122 \pm 1)$ and maximum in exp-4 $(142.3 \pm 1.5)$ and Catalase maximum value was recorded in exp-4 (186 \pm 0.5$)$ and minimum in exp-1 and $2(168 \pm 0.5)$

Table 2. Analysis of Hematological Parameters in fish (Labeo rohita)

\begin{tabular}{|c|c|c|c|c|c|c|}
\hline PARAMETERS & UNITS & $\begin{array}{c}\text { Control } \\
(\mathbf{A} . \mathbf{j}-\mathbf{)}\end{array}$ & $\begin{array}{c}\text { Exp-1 } \\
\mathbf{( A . j ~ 0 . 5 ~ g ) ~}\end{array}$ & $\begin{array}{c}\text { Exp-2 } \\
\mathbf{( A . j ~ 1 . 0 ~ g ) ~}\end{array}$ & $\begin{array}{c}\text { Exp-3 } \\
(\mathbf{A} . \mathbf{j} 1.5 \text { g) }\end{array}$ & $\begin{array}{c}\text { Exp-4 } \\
\mathbf{( A . j ~ 2 . 0 ~ g ) ~}\end{array}$ \\
\hline Hemoglobin & GMS\% & $33.3 \pm 0.1^{\mathrm{b}}$ & $33.1 \pm 0.15^{\mathrm{c}}$ & $32.8 \pm 0.02^{\mathrm{d}}$ & $33.8 \pm 0.01^{\mathrm{a}}$ & $33.8 \pm 0.01^{\mathrm{a}}$ \\
\hline WBC & CELLS/cmm & $27.9 \pm 3^{\mathrm{b}}$ & $27.8 \pm 2.08^{\mathrm{d}}$ & $27.8 \pm 2^{\mathrm{c}}$ & $27.7 \pm 2.64^{\mathrm{e}}$ & $28.1 \pm 2^{\mathrm{a}}$ \\
\hline Neutrophils & $\%$ & $29.4 \pm 0.15^{\mathrm{bc}}$ & $29.2 \pm 0.1^{\mathrm{c}}$ & $29.6 \pm 0.15^{\mathrm{b}}$ & $30.2 \pm 0.1^{\mathrm{a}}$ & $30.3 \pm 0.05^{\mathrm{a}}$ \\
\hline Lymphocytes & $\%$ & $63.1 \pm 0.05^{\mathrm{d}}$ & $63.4 \pm 0.05^{\mathrm{c}}$ & $63.6 \pm 0.05^{\mathrm{b}}$ & $63.8 \pm 0.1^{\mathrm{b}}$ & $68.2 \pm 0.15^{\mathrm{a}}$ \\
\hline Eosinophils & $\%$ & $1.73 \pm 0.05^{\mathrm{a}}$ & $1.3 \pm 0.11^{\mathrm{b}}$ & $1.83 \pm 0.05^{\mathrm{a}}$ & $1.76 \pm 0.11^{\mathrm{a}}$ & $1.8 \pm 0.05^{\mathrm{a}}$ \\
\hline Monocytes & $\%$ & $5.8 \pm 0.1^{\mathrm{b}}$ & $5.1 \pm 0.1^{\mathrm{c}}$ & $5.8 \pm 0.05^{\mathrm{b}}$ & $5.8 \pm 0.1^{\mathrm{b}}$ & $6.2 \pm 0.1^{\mathrm{a}}$ \\
\hline RBC & Millions/cmm & $2.28 \pm 0.01^{\mathrm{d}}$ & $2.18 \pm 0.01^{\mathrm{e}}$ & $2.82 \pm 0.01^{\mathrm{c}}$ & $2.91 \pm 0.01^{\mathrm{b}}$ & $2.98 \pm 0.01^{\mathrm{a}}$ \\
\hline Hct & $\%$ & $16.4 \pm 0.01^{\mathrm{c}}$ & $16.4 \pm 0.03^{\mathrm{c}}$ & $16.8 \pm 0.01^{\mathrm{a}}$ & $16.7 \pm 0.01^{\mathrm{b}}$ & $16.8 \pm 0.01^{\mathrm{a}}$ \\
\hline MCV & $\mathrm{fl}$ & $71.9 \pm 0.02^{\mathrm{c}}$ & $71.6 \pm 0.01^{\mathrm{d}}$ & $78.6 \pm 0.01^{\mathrm{b}}$ & $78.82 \pm 0.02^{\mathrm{a}}$ & $78.81 \pm 0.01^{\mathrm{a}}$ \\
\hline MCH & $\mathrm{pg}$ & $67.1 \pm 0.05^{\mathrm{d}}$ & $66.8 \pm 0.05^{\mathrm{e}}$ & $68.21 \pm 0.01^{\mathrm{c}}$ & $68.6 \pm 0.01^{\mathrm{b}}$ & $68.8 \pm 0.01^{\mathrm{a}}$ \\
\hline MCHC & $\mathrm{g} / \mathrm{dl}$ & $93.3 \pm 0.05^{\mathrm{c}}$ & $93.1 \pm 0.11^{\mathrm{c}}$ & $96.3 \pm 0.05^{\mathrm{b}}$ & $96.6 \pm 0.37^{\mathrm{b}}$ & $98.1 \pm 0.05^{\mathrm{a}}$ \\
\hline
\end{tabular}

(A.j: Aerva javanica, Exp: Experiment, g: gram) 
Data expressed as mean \pm SD $(n=3)$

Within rows values with different superscripts are significantly different $(\mathrm{P}<0.05)$

Table 3. Analysis of Biochemical Parameters in fish (Labeo rohita)

\begin{tabular}{|c|c|c|c|c|c|c|}
\hline Parameters & units & Control (A. j - ) & $\begin{array}{c}\text { Exp-1 } \\
(\text { A.J 0.5g) }\end{array}$ & $\begin{array}{c}\text { Exp-2 } \\
(\text { A.J 1.0g) }\end{array}$ & $\begin{array}{c}\text { Exp-3 } \\
(\text { A.J 1.5g) }\end{array}$ & $\begin{array}{c}\text { Exp -4 } \\
(\text { A.J 2.0g) }\end{array}$ \\
\hline Total protein & g/dl & $7.81 \pm 0.01^{\mathrm{b}}$ & $7.12 \pm 0.02^{\mathrm{d}}$ & $7.61 \pm 0.01^{\mathrm{c}}$ & $7.82 \pm 0.02^{\mathrm{b}}$ & $8.61 \pm 0.01^{\mathrm{a}}$ \\
\hline Albumin & $\mathrm{g} / \mathrm{dl}$ & $4.21 \pm 0.01^{\mathrm{c}}$ & $4.12 \pm 0.02^{\mathrm{d}}$ & $4.22 \pm 0.02^{\mathrm{c}}$ & $4.82 \pm 0.02^{\mathrm{b}}$ & $4.92 \pm 0.02^{\mathrm{a}}$ \\
\hline Globulin & $\mathrm{g} / \mathrm{dl}$ & $3.62 \pm 0.02^{\mathrm{d}}$ & $3.31 \pm 0.01^{\mathrm{e}}$ & $3.82 \pm 0.02^{\mathrm{c}}$ & $3.91 \pm 0.01^{\mathrm{b}}$ & $4.21 \pm 0.05^{\mathrm{a}}$ \\
\hline Blood Glucose & MGMS\% & $138 \pm 1^{\mathrm{b}}$ & $132.3 \pm 1.5^{\mathrm{c}}$ & $138 \pm 1^{\mathrm{b}}$ & $141.6 \pm 2.08^{\mathrm{a}}$ & $143.3 \pm 1.5^{\mathrm{a}}$ \\
\hline
\end{tabular}

(A.j: Aerva javanica, Exp: Experiment, g: gram)

Data expressed as mean \pm SD $(n=3)$

Within rows values with different superscripts are significantly different $(\mathrm{P}<0.05)$

Table 4. Analysis of Immunological parameters in fish (Labeo rohita)

\begin{tabular}{|c|c|c|c|c|c|c|}
\hline Parameters & Units & Control (A.j - ) & Exp-1 (A.j.1.0g) & $\begin{array}{c}\text { Exp-2 (A.j } \\
1.0 \mathrm{~g})\end{array}$ & $\begin{array}{c}\text { Exp-3 (A.j } \\
1.5 g)\end{array}$ & Exp-4(A.J 2.0g) \\
\hline Lysozyme & $\mathrm{Pg} / \mathrm{ml}$ & $42.3 \pm 0.20^{\mathrm{e}}$ & $48.2 \pm 0.15^{\mathrm{b}}$ & $46.2 \pm 0.15^{\mathrm{d}}$ & $46.5 \pm 0.15^{\mathrm{c}}$ & $53.2 \pm 0.15^{\mathrm{a}}$ \\
\hline PhagocyteS & $\%$ & $113 \pm 1^{d}$ & $122 \pm 1^{\mathrm{c}}$ & $111 \pm 1^{\mathrm{e}}$ & $127 \pm 1^{\mathrm{b}}$ & $162 \pm 1^{\mathrm{a}}$ \\
\hline NBT Assay & $\%$ & $10.6 \pm 0.5^{\mathrm{d}}$ & $11.6 \pm 1.15^{\mathrm{cd}}$ & $12.6 \pm 0.5^{b c}$ & $13.6 \pm 0.5^{\mathrm{b}}$ & $15.3 \pm 0.5^{\mathrm{a}}$ \\
\hline SOD & $\mathrm{Mu} / \mathrm{l}$ & $103 \pm 1^{d}$ & $122 \pm 1^{\mathrm{c}}$ & $124 \pm 1^{\mathrm{c}}$ & $133 \pm 1^{\mathrm{b}}$ & $142.3 \pm 1.5^{\mathrm{a}}$ \\
\hline Catalase & $\mathrm{Mu} / \mathrm{l}$ & $161 \pm 1^{d}$ & $168 \pm 0.5^{c}$ & $168 \pm 0.5^{c}$ & $175 \pm 1^{\mathrm{b}}$ & $186 \pm 0.5^{\mathrm{a}}$ \\
\hline
\end{tabular}

(A.j: Aerva javanica, Exp: Experiment, g: gram)

Data expressed as mean \pm SD $(n=3)$

Within rows values with different superscripts are significantly different $(\mathrm{P}<0.05)$

\section{Discussion}

Haematological, Biochemical, Immunological parameters are important factors that could be considered for the fish diet quality assessment. Sahu et al., reported higher Rbc counts in Labeo rohita fingerlings fed with Mangifera indica [14]. Hajibeglu and Sudagar (2010) reported an increase in the number of Wbc in common carp fish with the use of dietary supplements containing herbal immune stimulants [15]. Cyprinus carpio fed with formulated feed with plant extract of Andrographis paniculata showed gradually increased the haemoglobin content in different day of treatment [16]. Abalaka et al., mentioned that increase plasma total protein counts in Clarias gariepinus fish fed with aqueous and ethanolic extracts of Parkia biglobosa [17]. Masoud haghigh etal., reported the Origanum vulgare extract had significant $(p<0.05)$ effect in increase of total protein, albumin and globulin in Oncorhynchus mykiss fingerlings [18]. Ojha etal., reported there was a significant effect $(\mathrm{p}<0.05)$ of Mucuna pruriens supplementation on the blood glucose level of the different experimental groups in Labeo rohita fingerlings [19]. A variety of medicinal herbs like Curcuma longa, zingiber officinale, Allium sativum are known to stimulate phagocyte cells [20]. Pavaraj et al., reported that Ocimum sanctum leaf extract enhance the phagocytic activity in the C.carpio [21]. Treatment of albino rats with aqueous extract of freshly plucked Ageratum conyzoides leaves displayed escalation catalase and Sod activity [22]. Lysozyme activity significantly $(p<0.05)$ enhanced in fish fed with $1 \%$ of Origanum vulgare extract in Oncorhynchus mykiss [18]. Nbt increased significantly in the group fed $1 \%$ powdered zingiber officinale compared to control group in the fish Oncorhynchus mykiss [23]. 


\section{Graphical Analysis}

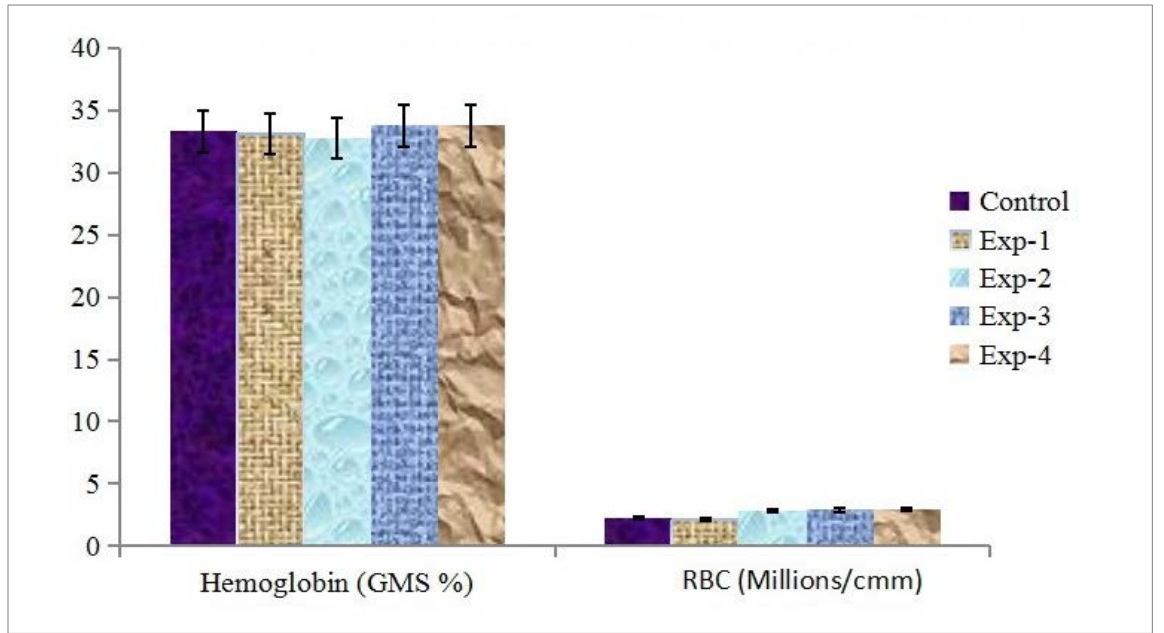

Figure 1. Level of Hemoglobin and RBC in Labeo rohita

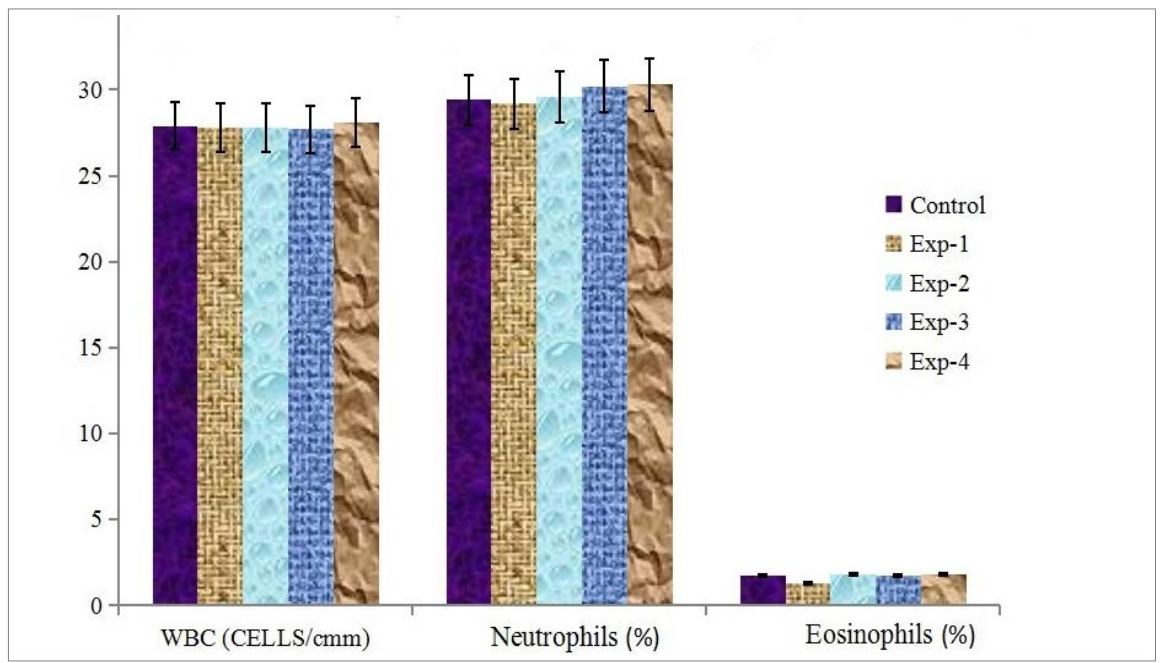

Figure 2. Level of WBC, Neutrophils and Eosinophils in Labeo rohita

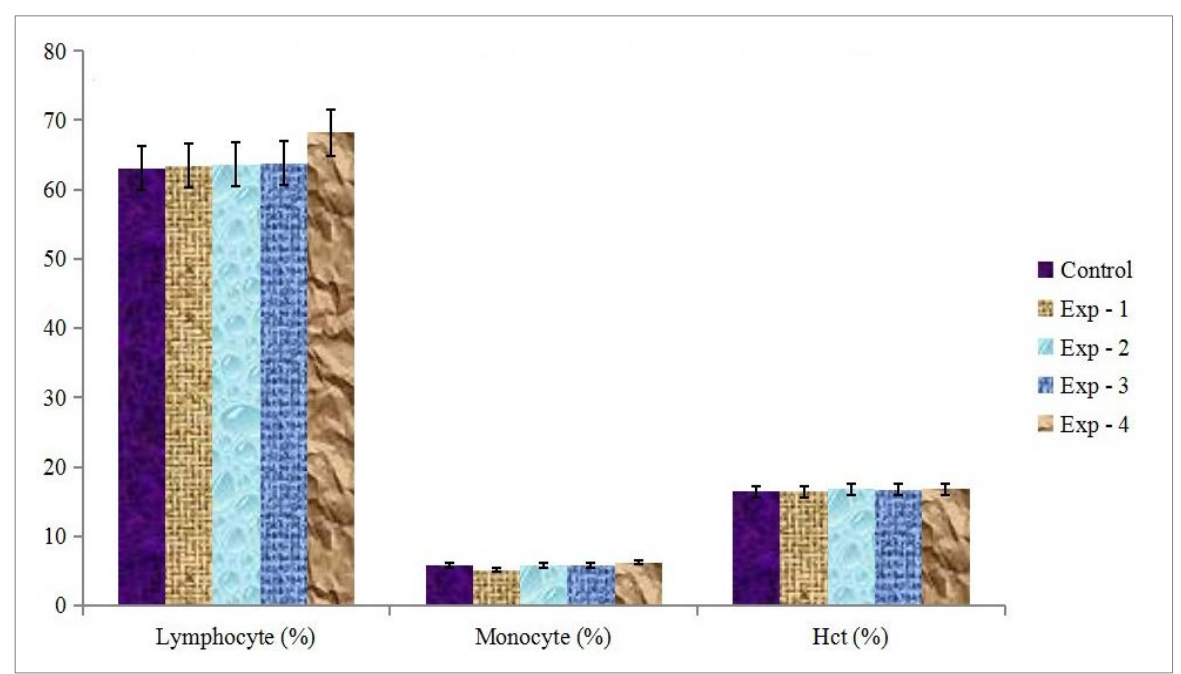


Figure 3. Level of Lymphocyte, Monocyte and Hct in Labeo rohita

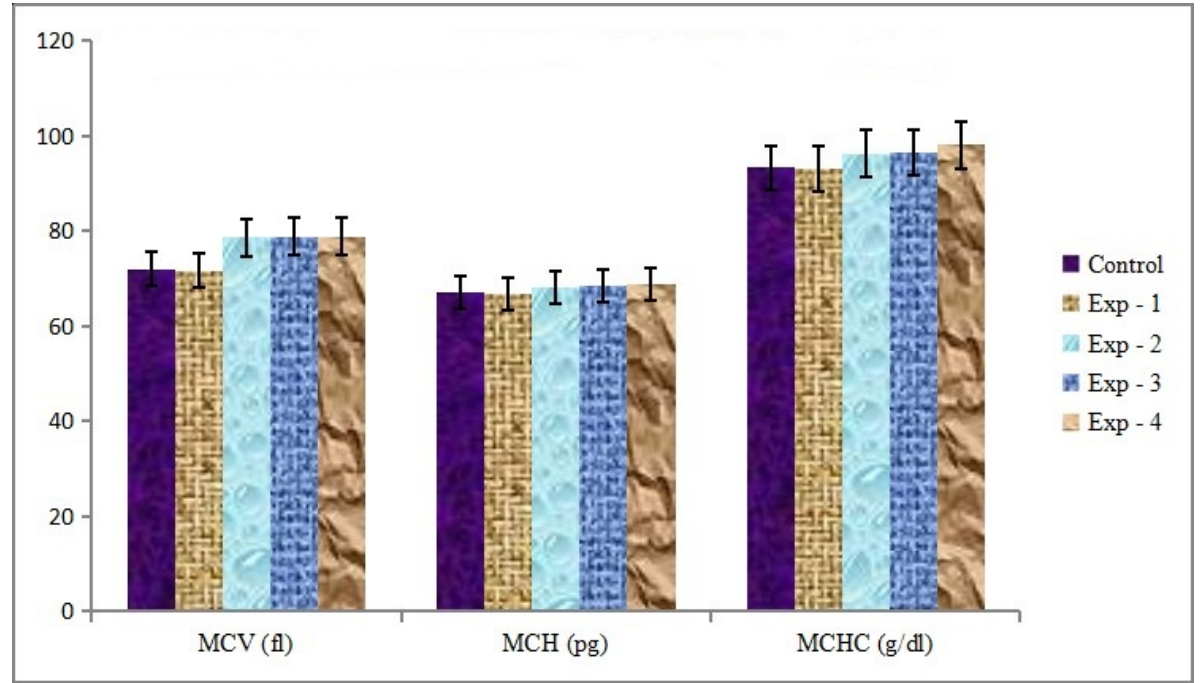

Figure 4. Levels of MCV, MCH and MCHC in Labeo rohita

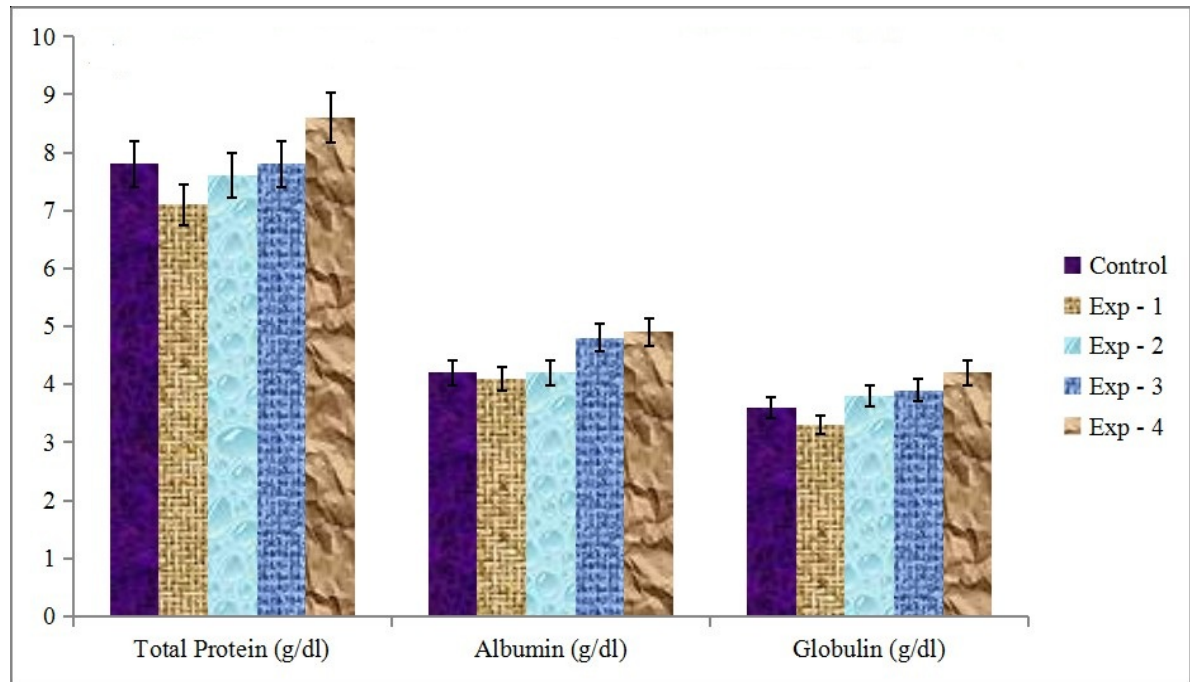

Figure 5. Level of Total Protein, Albumin and Globulin in Labeo rohita

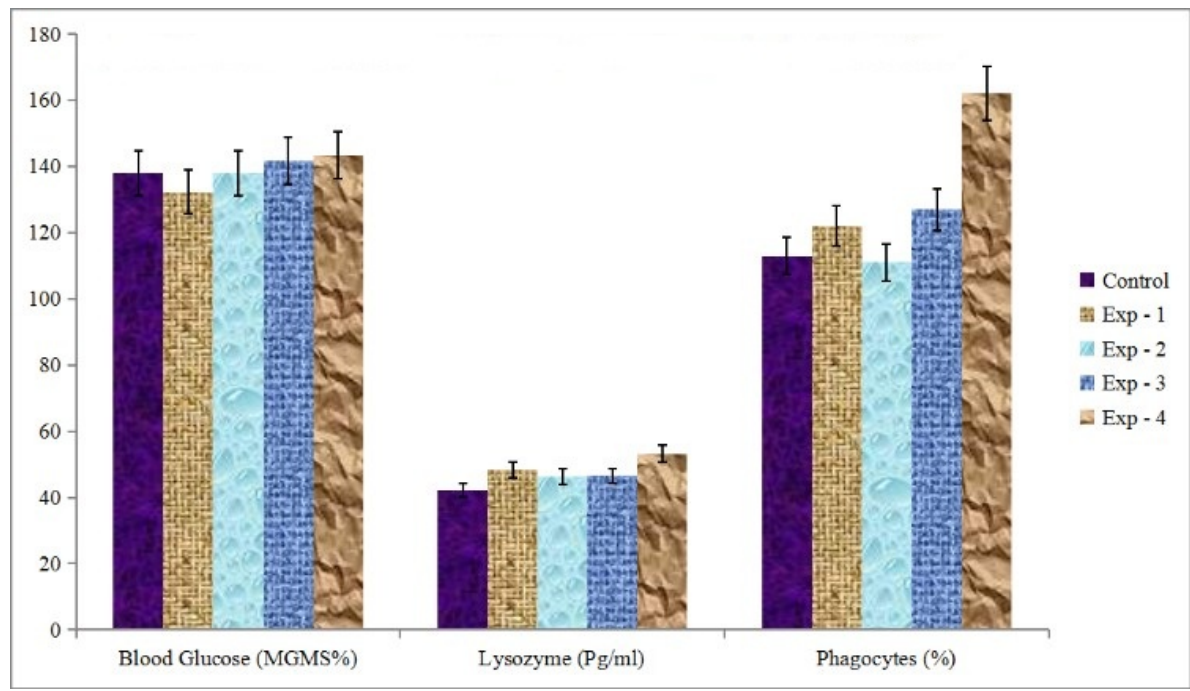

Figure 6. Level of Blood Glucose, Lysozyme and Phagocytes in Labeo rohita 


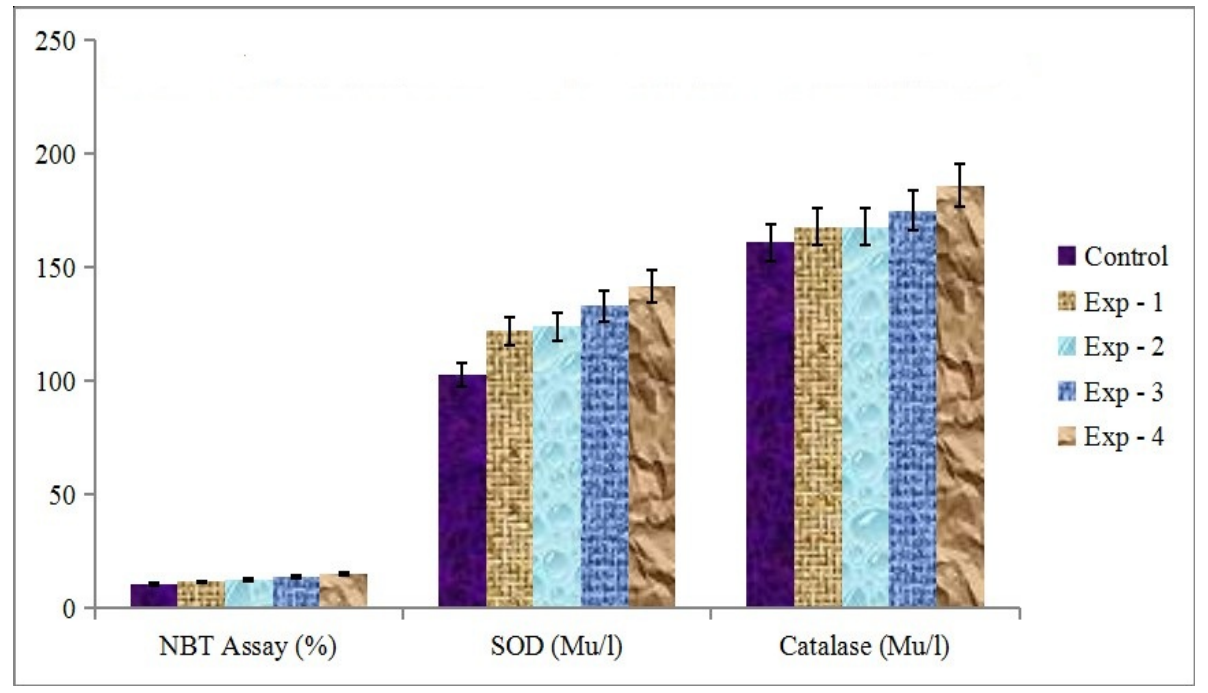

Figure 7. Level of NBT Assay, SOD and Catalase in Labeo rohita

\section{Conclusions}

The results and discussion of present study Prove a role of Aerva javanica (in powder form) supplemented diet has enhanced Hematological, Bio chemical and Immunological parameters in the fish of Labeo rohita fingerlings. Conclusively the Aerva javanica herbal feed supplements promote growth, minimizes stress improves immunity which could help prevent various infections in fishes.

\section{REFERENCES}

[1] Asimi OA, Sahu NP. Herbs/spices as feed additive in aquaculture. Sci J Pure Appl Sci. 2013;2(8):284-92.

[2] Balasubramanian G, Sarathi M, Kumar SR, Hameed ASS. Screening the antiviral activity of Indian medicinal plants against white spot syndrome virus in shrimp. Aquaculture. 2007;263(1-4):15-9.

[3] Secombes CJ. Techniques in Fish Immunology. SOS Publication. SOS publications. Fair Haven; 1990. 101-104 p.

[4] Blaxhall PC, Daisley KW. Routine haematological methods for use with fish blood. J Fish Biol. 1973;5(6):771-81.

[5] Schreck CB, Moyle PB (ed). Methods for Fish Biology. American Fisheries Society Publication; 1990. 272-334 p.

[6] Verma A. Practical Clinical Biochemistry. 5th ed. Practical Clinical Biochemistry. CBS publication; 2013. 479-480 p.

[7] Anderson D, Klontz GW. Basic hematology for the fish culturist. In: Northwest Fish culture conference. 1965. p. $38-41$.

[8] Ivanova NT. Atlas of fish blood cells. LPP Moscow; 1983.

[9] Bricknell IR, Bowden TJ, Bruno DW, MacLachlan P, Johnstone R, Ellis AE. Susceptibility of Atlantic halibut,
Hippoglossus hippoglossus (L.) to infection with typical and atypical Aeromonas salmonicida. Aquaculture. 1999;175(1-2):1-13.

[10] Siwicki AK, Anderson DP. Phagocytic index readings in fish. In: Nordic symposium on fish immunology. 1993.

[11] Siwicki AK, Anderson DP. NBT activity by spectrophotometric assays. In: Nordic symposium on fish immunology. 1993.

[12] Mccord J, Fridovich I. McCOrd, J. M., and Fridovich, I. Superoxide dismutase. An enzymic function for erythrocuprein (hemocuprein). J. Biol. Chem. J Biol Chem. 1969; 244:6049-55.

[13] Aebi H. Catalase A2 - Bergmeyer, Hans Ulrich. In: Methods of Enzymatic Analysis (Second Edition) [Internet]. 5th ed. NBew York: Academic Press incorporated; 1974. p. 67384. Available from: http://www.sciencedirect.com/science/ article/pii/B9780120913022500323

[14] Sahu S, Das BK, Pradhan J, Mohapatra BC, Mishra BK, Sarangi N. Effect of Magnifera indica kernel as a feed additive on immunity and resistance to Aeromonas hydrophila in Labeo rohita fingerlings. Fish Shellfish Immunol. 2007;23(1):109-18.

[15] Abasali H, Mohamad S. Immune response of common carp (cyprinus carpio) fed with herbal immunostimulants diets. J Anim Vet Adv. 2010;9(13):1839-47.

[16] Muthu R, Pavaraj M, Balasubramanian V, Rajan MK. Haematological Studies on Disease Induced Common Carp, Cyprinus carpio Fed with Formulated Feed with Plant Extract of Andrographis paniculata. World J Zool. 2015;10(1):9-12.

[17] Abalaka SE, Esievo KAN, Shoyinka SVO. Evaluation of biochemical changes in clarias gariepinus adults exposed to aqueous and thanolic extracts of parkia biglobosa pods. African J Biotechnol. 2011;10(2):234-40.

[18] Haghighi M. Effect of Origanum vulgare Extract on Immune Responses and Heamatological Parameters of Rainbow Trout (Oncorhynchus mykiss). Oceanogr $\{\&\}$ Fish Open Access J. 2018;6(3). 
[19] Ojha ML, Chadha NK, Saini VP, Damroy S, Chandraprakash, Sawant PB. Effect of ethanolic extract of Mucuna pruriens on growth and haematology of Labeo rohita fingerlings. Ecol Environ Conserv. 2013;19(3):90712.

[20] Alambra JR, Alenton RRR, Gulpeo PCR, Mecenas CL, Miranda AP, Thomas RC, et al. Immunomodulatory effects of turmeric, Curcuma longa (Magnoliophyta, Zingiberaceae) on Macrobrachium rosenbergii (Crustacea, Palaemonidae) against Vibrio alginolyticus (Proteobacteria, Vibrionaceae). AACL Bioflux. 2012;5(1):13-7.

[21] Pavaraj M, Balasubramanian V, Baskaran S, Ramasamy P. Development of immunity by extract of medicinal plant Ocimum sanctum on common carp Cyprinus carpio (L.). Res J Immunol. 2011;4(1):12-8.

[22] N AK, Emmanuel OC. Amylase Activity in Albino Rats Treated with Painkil Tablets (Analgesic). IOSR J Dent Med Sci Ver IV [Internet]. 2015;14(10):2279-861. Available from: www.iosrjournals.org

[23] Haghighi M, Rohani MS. The effects of powdered ginger (Zingiber officinale) on the haematological and immunological parameters of rainbow trout Oncorhynchus mykiss. J Med Plant Herb Ther Res. 2013;1(1):8-12. 